\title{
National-Specific Features of the New Avant-Garde Egyptian Prose of the Late 20th Century
}

\author{
Rashida R. El Sabruti ${ }^{1}$ \\ ${ }^{1}$ Kazan (Volga Region) Federal University, Kazan, Russia \\ Correspondence: Rashida R. El Sabruti, Kazan (Volga Region) Federal University, 420008, Kazan, Kremlyovskaya \\ Street 18, Russia. E-mail: erashida@yandex.ru
}

Received: June 2, 2015 Accepted: June 15, 2015 Online Published: June 29, 2015

doi:10.5539/jsd.v8n5p19 URL: http://dx.doi.org/10.5539/jsd.v8n5p19

\begin{abstract}
The fact is that up-to date there are no researches concerning avant-garde prose of Egypt aimed at defining its national-specific features, the prose is hardly known to domestic and western literary criticism. Therefore the object of the study is to reveal the best samples of avant-garde Egyptian prose, reflecting postmodernism esthetics and to show their national and specific features. At the present time the integrated method of the analysis of the literary text is of great importance. The main method of our research is a conceptual and contextual analysis of the chosen works of art from the position of hermeneutic and esthetic direction of philological researches. The results of the research show that modern Egyptian prose, mastering the intellectual experience of world culture within the frame of the national cultural heritage, revealed a new technique and brought new contents to literature. The innovation is defined by orientation of the authors to mythological transplantation of figurative system. There is a multilevel organization of the text, an encryption of semantic layers, destruction of a traditional subject basis. The materials of the article can be useful for the development of the manual on the world literature, stylistics of the Arabic language and translation practice.
\end{abstract}

Keywords: modern Egyptian prose, concept of postmodernism, Sufism, avant-garde esthetics, heritage of world culture.

\section{Introduction}

\subsection{Relevance of the Dialogue of Ethnic Contents Culture with World Culture}

According to the most literary critics postmodernism became one of the leading directions in the world culture and the culture of the latest quarter of the 20th century (Kubareva, 2002). In the esthetic relation postmodernism is focused on the cultural experience of last eras, and as its principle the versatility of the points of view which proceeded from a variety of world around was taken (Statsenko, 2002).

The features of postmodernism in the world literature were revealed in the 60s of the 20th century (Ilyin \& Tsurganova, 2006). The writers of this school were oriented on perception of the world as the chaos. The only reality for them was the reality of culture and world as a literary text (Ilyin, 1990).

No doubt that the European experience had a huge impact on the development of the modern Arab culture. Art practice of the Egyptian writers tells about synthesis of elements of the European esthetic school. However the prose of Egypt is the result of centuries-old Arab literary tradition. Sometimes people of art derive their inspiration from traditions of the national past connection which makes their creative works much better. The Arab philologists note that the forms of the Arab prose have qualitatively changed (Kassim, 1994). They are far from a classical form based on substantial centers. A new novel became a versatile one. In comparison with traditional paradigms, the existential organization of the art world became complicated (Abu Uf, 1994).

\subsection{Arab Avant-Garde School}

In the Arab world avant-gardism appeared in the forties of the 20th century in the works of the Arab writers who joined the Art and Freedom magazine (Kassim, 1994). However they were bitterly criticized by the representatives of traditional school and were rejected by censorship. When the European modernism gained the stage of modernism, the Arab avant-gardism continued to fight for recognition of its existence in the world of art. There are completely different points of view on such notions as modernism and avant-gardism (Sarukhanyan, 2010). 
In the territory of the Arab East, in the second half of the 20th century scientific thought takes the forms of historical categories and categories of national culture. At the turn of 70-80s, the elite postmodernism following the slogan "art for art" becomes one of the poles of literary process in Egypt. Representatives of post-modernist school were such writers as Byadr ad- Dib, Eduard al-Harrat, Iatidyal Osman, Gamyal al-Gytani, Muntasar al-Kaffyash, Naser al-Halyauani and others. These writers don't consider their works as the story or the novel. Byadr ad- Dib, as an example, describes his work "Kholmy zakhoda" as a collection of everyday or religious sketches, and the work "Vysota i nerealnost" as a description of the knowledge of life experience in the dialectics of existence. The writer Iatidyal Osman sees in her work "More Younisa" an ordinary literary text (Kassim, 1994). The writers of postmodernism consider that everything they write is beyond traditional genres. While interpreting the works, they use a widespread European term "clear text" as they take them as the texture combining all types of literary genres up to poetry. As a result the term "story poetry", offered by Eduard al-Harratom, which was numerously criticized by Arab philologists was invented (Kassim, 1994).

Postmodernism is an international phenomenon, it generates different approaches to its principles. The Egyptian writers of new avant-garde school modeled a world order as they see it. Based on the potential of culture of the past, they created a highly intellectual language. Their works against the background of traditional forms of narration were an unusual improvisation, the main goal of which was overthrowing the existing standards and creation of a new reality.

\subsection{Characteristic Features of the Arab Post-Modernist Text}

The heroes of the Egyptian prose of 80-90 years were considered to be the product of their time. However there were taken the attempts to bring heroes to a rank of universal time and space, to reflect reality through images symbols. The myth was considered as one of the forms of art convention where the real, but poorly studied vital process was highlighted. In the course of time, a traditional plot has been changed. (Abu Uuf, 1994). The image of the person became less developed. The authors of the post-modernist novel showed a masterly game with time and space.

The new literature was characterized by the intention "to tell something" and at the same time "to tell nothing" as the absurd world which lost reference points, in their opinion, can find its reflection only in an absurd form. The attempt of the Arab writers to find something common in existentialism and Muslim Sufism was dictated by desire to bring the scientific base under the religious doctrine and in such way to strengthen the authority of religion (Aganina and Chelyshev, 1989). The attraction of their creativity is that they rejected dogmatism in the sphere of arts and knowledge. And it designates break in the sphere of art creativity, separation of its horizons for search and a reconstruction of new truth and renovation of the level of Arab culture.

\section{Materials, Method and the Course of Research}

\subsection{Research Hypothesis}

The European experience of the development of modern Arab culture is very obvious. Postmodernism directly comes to a dialogue with culture of ethnic contents (Shibanov, 2007). However Arab writers, being close to post-modernist stylistics of the West, are beyond the world outlook orientation. It will be more lawful to speak about the existence of elements of the western post-modernist letter in works of writers whom we have chosen. Acculturation of art energies, connection of tradition with innovation allowed formulating a hypothesis of the offered work: national and specific features of new avant-garde prose of Egypt. The process of perception of a conceptual basis of the chosen material is designed for a trained professional.

\subsection{Research Problems}

Due to importance of the studied problem the purpose of the article was formulated, namely: research of the best samples of the Egyptian prose reflecting a postmodernism esthetics. The novel Gamyalya al-Gytani "Kniga providenii" (Gytani, 1990), and Eduard al-Harrata's trilogy " Rama i dracon" (Harrat, 1980), "Inoye vremya" (Harrat, 1985) and "Istina zhazhdy" (Harrat, 1996) were taken as a material. The following task was set up: to trace the tendency of the writers to medieval philosophy of Sufism, to show how the genre of the European avant-garde school with the Arab medieval heritage merges. The methodological basis of the research was formed by the works of the leading Russian and Arab philologists.

The research was conducted on the material of the Arabic language. The analysis of the vocabulary was carried out within the frame of the problems connected with a social nature of the language under the impact of extralinguistic factors on the language. 


\subsection{Integrative Nature of the Research}

The object of philological research is a text which is formed as a product of communicative activity of people and culture of society. An integrative nature of the philological research of the world literature is shown in the importance of the linguistic, ethnic and culturological analysis of the text. Understanding the word in its common-language value makes it possible to consider the word in the structure of a verbal artistic image (Valgina, 1998). For the development of a hypothesis the empirical method including esthetic, social and cultural experience of the author of article was used.

\subsection{Sources of the Analysis and the Course of Research}

Eduard al-Harrat's works are the samples of the Egyptian experimental novel. His literary creative works surprised critics and readers, it took an honourable place in the union of writers of the Afro-Asian countries (Roman segodnya, 1994). Actively using the technique of postmodernism in his works, the writer gives to their "foggy" reality the unusual form. Visually it can be traced in his trilogy united by the same heroes and the same subject. It more reminds a fragmental mosaic where the author tries to transfer the idea of heterogeneity and a chaotic state of the world around (Al Sabruti, 2013).

The first novel "Rama i Dracon" is divided into chapters, each of which can be considered as a separate story, but all of them are connected with the subject matter of the struggle of the Saint with the Devil. The novel begins with the end of the events. Its first part under the title "Mikhail and Lebed" transfers a tragic end of a love story where the swan symbolizing Rama is killed. In his second novel "Inoye vremya" the intention of the hero to divine love and ideal time is expressed. The religious and philosophical subject is presented in the third novel "Istina zhazhdy".

The author in the novels is a story-teller and a hero at the same time whose image constantly changes. Taking a middle position in using the expression "and his inner voice said", he resorts to technique of promoting consciousness (Abd al-Muttalib, 2001). This method helps the author to disclose deep secrets of the hero, and a detailed observation of a panorama of events. The hero of the novel Mikhail, in his intention to divine love and ideal time, tries to overcome the evil forces preventing him from achieving a desirable aim.

The art space of the novel contains the local reality and the global imaginary world. When describing the church's altar in «Rama i dracon" we see how the joy of the hero merges with the greatness of the altar where the atmosphere of spiritual calmness and prosperity reigns and the time stops:" The gloomy sky of my heart is suddenly consecrated inside, it starts shining, its falling stops. It does not exist anymore. One can feel lightness with which nothing can be compared, and the weightiness disappears somewhere. The flowers of my heart painted in red, violet and other tones of arrogance with wild pleasure sprout on a colored glass of the heated sky. The sun is calm. The grandiose silence and calmness reign. Majesty is enormous."

The text of the trilogy is generative. There are several texts in it. The style is a leading force of the novel, there is a destruction of a subject basis of the work where it is impossible to build a chronological sequence of events, the plot becomes fragmentary (Abu Rafia, 2000). We observe the technique of free transition from the reality to the imaginary, from the present to the past. The author comes back to the pharaonic past which is connected with the events of modern Egypt, its instability and contradictions. A black mask is a personification of lie and hypocrisy of consumer society. The mask pursues imagination of the hero, further it becomes a part of his body, then his face turns into a mask. The author tries to transfer the idea of a crisis epoch, exchange of values, a chaos state of the world.

While choosing the names the writer pays great attention to their meanings. The name "Rama" comes from the Arabic verb, denoting an intention to achieve a desirable aim. The heroine personifies the beloved whom the hero aspires to. He looks for her inside and around himself (Badr, 2008). The name "Mikhail" embodies the qualities of St. Angel Mikhail, it transfers desire of the hero to exceed the human potential. Using religious and historical semantics of the names, the writer tries to show the concept of divine love.

Describing Rama, the author uses the mythological image of a phoenix symbolizing knowledge that updates all the time. Generally, the image of Rama is a gathering one. It combines conditional and mythological elements and historical images. On the basis of pharaonic heritage we get to know about Izis, Hatkur and Mirit. Then we move into the era of the Arab queen Balkys. Here we can meet on the one hand, a modern princess Diana, and on the other hand, ordinary Egyptian girls Bakhiga and Fatima. Due to such images Rama can freely move in art space between eras, between the myth and reality.

The Fight of fair people over temptations of life is expressed by Mikhail's fight with a dragon. The dragon symbolizes a devil and prevents the hero and Rama from being together. The fight with the dragon is difficult, 
and the hero realizes that "from his beaten-out teeth thousands of new dragons will appear". But at the end he defeats the dragon. The idea of the work is expressed in an unusual art form where the sufiysky doctrine unites with magic fantastic pictures.

A characteristic feature of medieval sufiysky heritage is a flight into the space and a dialogue with an invisible other world. Using metaphors, sufists tried to make the abstract world a real one, to make the life living and breathing. Sufiysky stages of a thorny road into the absolute space in the novel "Inoye vremya" begin with the sufferings which are symbolically expressed by falling of a ceiling in the Palestinian temple. Mikhail is the personification of the image who tries to overcome difficulties, and the pigeon is the symbol of happiness.

The author successfully uses the technique of sufiysky dialogue for formulating desire to be free in this world. Mikhail divides his life into two opposite worlds: - the first is temporary, and another - eternal : "I miss another Mikhail, as an ideal of courage from a remote childhood. I want to touch him, but I can't. Two different creatures - I and another I. We know each other very well, but there is a strange invisible wall between us which is impossible to pass through".

The Sufiysky heritage was written in rhymed prose, the frequent use of antonyms was represented by the dialogue rich with antagonism that one can find in the second novel "Inoye vremya": "Intensity and stability, division and integration replace each other in endless consequence, repeated rhythm, various frequency of fluctuation".

It is possible to tell that the second and third novels are an improvisation to the novel "Rama i Dracon". The key to profound judgment of the contents and philosophical subject of the third novel "Istina Zhazhdy" is an epigraph from classical Arab poetry. This method generates dialogue of a modern era with the Arab cultural heritage and creates the hypertext. For post-modernist literature it is characteristic to include into the text borrowings from a wide range of texts of the previous eras and to use transformation of classical motives .

The elements of the West European post-modernist letter are traced in the novel Gyamyalya al-Gytani "Kniga providenij". The name of the novel reminds us of the book written by one of the greatest authorities of medieval Sufism - Ibn Arabi called "Bozhestvennye provideniya". The novel is divided into 3 Scriptuses, each of which is divided on "stops" and "situations". Stops presuppose the image of human life and refusal from the world benefits stage by stage. The state of "Death" in the doctrine of Sufism means spiritual regeneration, and a constituent of stop- spiritual vision of the Stored Skrizhaliya, as a mirror substance reflecting all events of the last, real and future world. "Death" is the beginning of a new spiritual development, a condition of non-existence through which it is possible to pass into a stage of "eternity" and come to the God (Sabruta ale, 2012).

The narration is told by a story-teller who wants to comprehend the highest truth by means of self-improvement. The first lines of the novel have something in common with one of the key positions of Sufism: "I made my way to the Truth". The writer observes the images of people of the past, having compared them face to face with the present in his novel. The author uses such terms as "discovery" and "miracle". Thanks to a miracle, a story-teller gets an opportunity to fly about the whole world and to see what ordinary people do not see. When he turned to be with his teacher in the mosque of Moroccan city FAS, a surprising show opened before him: "After an appeal to a prayer I saw how the people who reached perfection entered there. They came from distant and different eras. I saw our father -Adam, or Yusin in a womb of a whale, and the tortures on Jesus's face at the minute of his crucifixion".

The plot of the work is based on the comparison of the myth and reality: "I saw a strange bird, of an unimaginable form and color: feathers -a mixture of colours, a head human, and a human face. This strange bird seemed to soar in the air. Her flight is her fall, and her fall is her flight". Crossing the borders of reality, the writer pursues the aim to approach the absolute truth, to see the world hidden for us, to hear the sounds of Universe: "I heard the call of the branches, the talk of the stones, the whisper of the stars, dew polemics, the speech of the winds, the sound of the falling meteorites, the invocation of comets, the groan of atom's splitting, the echo of unprecedented space of the far Universe".

Wanderings happen in imagination of the story-teller, and it is one of the most important aspects of suffism (Al-Vakil, 1998). The method of elimination of place and time boarders allowed the writer to compare greatness and beauty of the other world with life world. The term of suffism "settlement" means the stage coming after "death". In modern novels this term is limited to a unification of man with God, but the author of our novel uses it in the meaning of the resettlements of the dead in another living flesh. It replaces, for example, the hero story-teller's head with the head of the died Egyptian president: "And what surprised me is that my head is cut and without body. I saw my flesh going before me and my father, I was without a head and face. I saw the features of the dead president Nasyr on my face". 
The concept of existence is obviously reflected in the novel: "Am I here or there? Am I alive or dead? Am I something or nothing?" The author uses a method of the description of the pictures in the form of a dream: "I glanced at the fence at those far times. The range of my vision extended, I could see two subjects at the same time, to distinguish between the remote things, to examine the objects in the needle ear range, to catch their details". Each text in the novel is an intertext, based on the potential of the Arab history and culture. The author uses death of the Egyptian president Nasyr as the beginning of foresights. Describing a situation of modern Egypt, he comes back to its great historical past. The art space of the novel contains in itself two worlds: surrounding reality of the author and mythical space. According to the doctrine of one of founders of medieval Sufism Ibn Arabi, the world around us is an infinite vicious circle where there is neither the beginning nor the end. There is neither the past, nor the future, there is only the present (Ibn Arabi, 1997). In this doctrine the author of the novel chose the basis on which he forms the perception of the world not limited by the real facts and concrete forms of life. He addresses in the art and philosophical searches to the eternal and infinite universum understood as the animated space where "the borders of the beginning and the end are interlaced" and where "there is neither remote past, nor the future".

In the novel the time sense is lost: "I don't know how much time passed since the death of my father though I saw the moments of his birth, I saw his sufferings not in details, but in a flash". The writer "sees the father in his childhood whom his mother lulls" when he with his younger brother and father walks between houses of the native settlement.

According to suffism, only those who achieved the highest degree of consciousness can see the hidden world of the truth. It takes place in the novel during ascension of the story-teller from earthly space into unearthly where he finds "the Stored Skrizhaliya" that "can't be comprehended by a human mind". It is the spirit of the Universe, where there are human souls in those covers which we see (Abu Zeyd, 1998).

The author describes the fantastic cities which are called as the cities of a foresight and light: "I don't know, how much time passed till I saw the city smothered in quiet light. I began to wander about its high walls. I noticed a small door with a drop of turquoise on it. I came in and saw multi-colored buildings, my heart trembled with surprise. I went on crystal paths where there was a play of light and colour ". Ibn Arabi, in his works describes something the like, having called it "the earth of truth" (Sabruta ale, 2012).

The picture of dreams is a strong point of continuous transformation of time. It seems that we do not deal with the reflected changing reality, but with the image of the dream deeply hidden in subconsciousness of the author. Every image has a social and psychological shade. Through the image of the father, the writer shows the life of the Egyptian working people: "I saw the body of the father gathering dates, clambering on trunks of palm trees. I saw him sleeping on straw at night, then working at the machine, filling the bags with flour. I saw him working in sun, picking up the worms, shepherding a herd of goats".

Following the principle of a foresight, the author invites to his creative arena an image of the great wise man Ibn Arabi which is known in Arab history as "Great Sheikh" thanks to his concept of unity of life. But the scientist and the philosopher gets the features of the present time. The novel is a dialogue with the past, and in particular with the heritage of creative works of Ibn Arabi and love of the hero to Lur is the echoes of the sufiysky love described in his "Tractat o lyubvi".

\section{Results}

A literary process of Egypt in the second half of the 20th century can be presented as inclination of creative tendencies to one of two poles - to neo-realism and postmodernism which were in a complex process of interaction. The art space of the Egyptian novel was developed in the context of the world culture, absorbing and developing new cultural trends, taking into consideration their own literary traditions and creative opportunities. Harrat and Gytani's innovation is defined by the author's orientation to the mythological transplantation of a figurative system. The idea of creative dialogue with predecessors and contemporaries is accumulated as the important principle of their work. It is necessary to mention a multileveled organization of the text and an encryption of semantic layers.

The priority of the style over the contents is observed the result of which there is a destruction of a traditional subject basis where it is impossible to build chronology of events and the plot becomes fragmentary. The sufiysky subject is the plot where there are no boarders between an abstract and material world. Mythical thinking is the main part of a literary style of the writers where the positions of fictional and real world are equalized.

The use of poetry in prose is taken by the writers from the Arab heritage. The choice of quotes from sufiysky 
heritage pursues detection of its deep philosophical meaning to which modern interpretation is given.

The vocabulary of the trilogy of Harrat is based on a modern spoken language, it is aimed at transferring life situations. The author is the master of comparing literary styles of different eras that is characteristic for post-modernist work which is considered to be a peculiar link. The writer has mental abilities which help him to abolish the standard principle of the organization of art material, to cover a large circle of historical and social cultural events. The mixture of time layers creates specific time of the work as certain universal time in which everything repeats and comes back. Different story-tellers confirm different forms of life.

The vocabulary of the novel after al-Gytani is classical. The style of his work reflects a stream of consciousness where object clauses prevail as well as short, laconic sentences. The structure of the sentences corresponds to the language of the dreams where the events pass quickly.

\section{Discussion}

The value of the works of the Egyptian writers who chose post-modernist orientation is that they expressed in an unusual and peculiar art form the problems which are of great importance even nowadays. The process of decoding of post-modernist style is very difficult, as Fomicheva fairly notices, it is a combination of esthetic, social and cultural experience of the reader (Fomicheva, 2011).

In the European and American literature many philologists of the world were engaged in research of history of development of post-modernist school and detection of its specific features. However Arab philologists studied the elements of the western post-modernist letter in their work. The Arab writers with a post-modernist esthetic orientation are hardly known in Russia and in the West. The given article offers its own vision of one of the important parts of literary process in the modern Arab East.

\section{Conclusion}

The exact assessment of any national experience is impossible without world experience today. According to most of literary critics postmodernism became one of the leading directions in the world literature. One can feel the influence of existentialism philosophy with its doctrine about freedom on the concept of postmodernist's writers. The followers of this philosophy consider that no tradition can be a monopoly.

Today postmodernism is comprehended not only, as a universal category of culture of the XX century, but also as an expression of the spirit of the time. Egyptian writers actively mastered a palette of world verbal art. The attraction of the works of Harrat and Gytani is that instead of a steady outlook of modern society they offered tolerance to an esthetic variety. All this meant break in the sphere of art creativity, disclosure of its horizons for search and reconstruction of new truth. But in conclusion, it should be noted that the level of works of different writers is defined as a measure of their own talent, but not the fact of belonging to this or that tendency.

Eduard al-Harrat and Gamyal al-Gytani, using the methods of sufiyskikh dreams, are considered to be the best ones among the novelists of the Arab East. A rich stylistic palette and unwarranted stretch of imagination of the author surprise critics and readers. But nevertheless the writers do not try to avoid the cruel reality of the world we live in .

\section{Recommendation}

The materials of research are of great importance for development and synthesis of world cultural heritage.

\section{Acknowledgments}

The work is performed according to the Russian Government Program of Competitive Growth of Kazan Federal University.

\section{References}

Abd al-Muttalib, M. (2001). Ritorica povestvovaniya. Kair. (in the Arabic language) بلاغـة :المطلبـب عبـد محمد

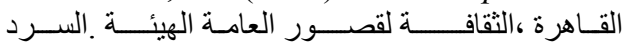

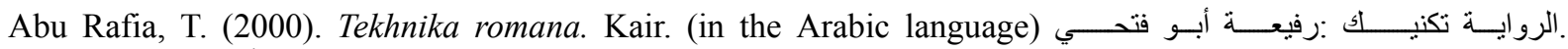

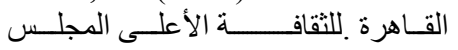

Abu Uuf abd ar-Rahman. (1994). Transformaziya obshchestva i yego rol v formirovanii khudozhestvennogo teksta. In Devyataya konferenziya yegipetskikh pisatelei: Literatura i vyzov budushchemu (128-150). Kair.

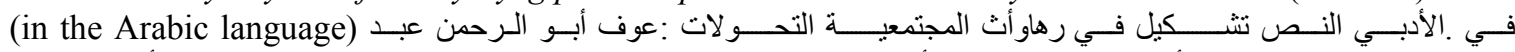

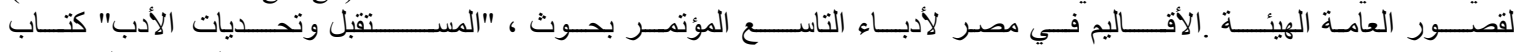

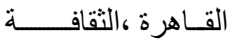


Abu Zeyd, N. H. (1998). Filosofiya tolkovaniya: razbor tractovki Korana u Ibn Arabi (Vyp. 4). Beirut. (in the

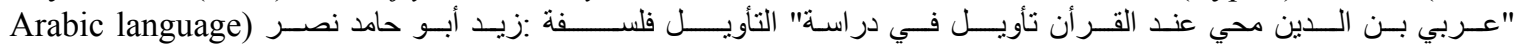

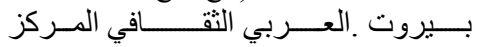

Aganina, L. A., \& Chelyshev, E. P. (1989). Literatura stran vostoka. V knige Istoriya zarubezhnoi literatury. Moskva.

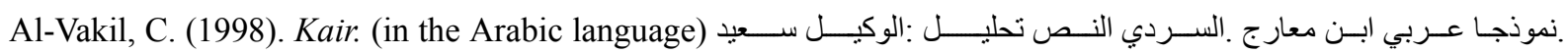

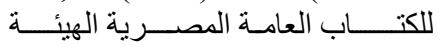

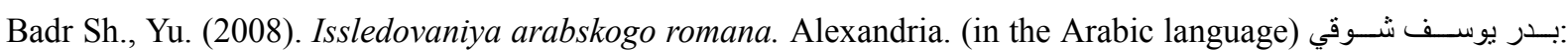

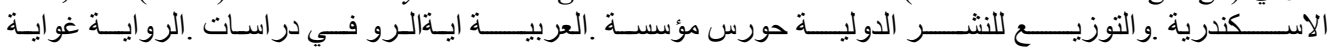

El sabruti, R. R. (2012). Sufijskaya tematika v romane Gytani “Kniga provideniy". Uchenye zapiski kazanskogo universiteta, tom 154, kniga 2.

El sabruti, R. R. (2013). Modelirovaniye novoi realnosti v postmodernistskom kontekste. Inostrannye yazyki: lingvisticheskiye I metodologicheskiye aspecty. TGU vyp.22.

Fomicheva, Zh. E. (2011). Ot modernisma $k$ postmodernismu :nekotorye aspekty smeny literaturno-khudozhestvennoi paradigmy. Nauchnye vedomosty Belgorodskogo gosudarstvennogo universiteta, 12.

Gytani, G. (1990). Kniga provideniy. Kair. (in the Arabic language) الأســفار .التجليــــات كتـاب :الغيطــاني جمال

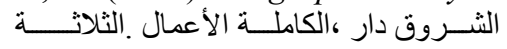

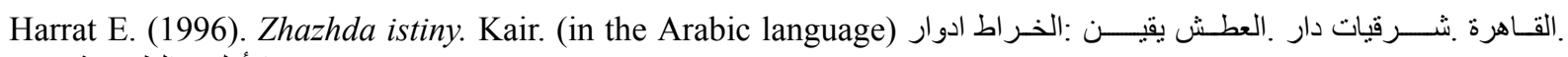

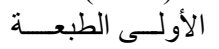

Harrat, E. (1980). Rama i dracon. Kair. (in the Arabic language) دار الأولـى؛ الطبعــة .والتتيــــن رامة :الخـراط ادوار

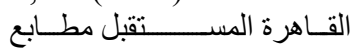

Harrat, E. (1985). Inoye vremya. Kair. (in the Arabic language) القـاهرة .شهدي دار .الآخر الزمن :الخـر اط ادوار

Ibn Arabi, M. (1997). Mekkanskiye lavry v postizhenii glubin filosofskikh shkol. Beirut. (in the Arabic language)

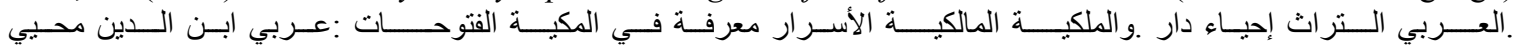

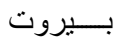

Ilyin, I. P. (1990). "Postmodernism" problema sootnosheniya tvorcheskikh metodov v sovremennom romane zapada. V knige.Sovremennyi roman.Opyt issledovaniya. Moskva.

Ilyin, I. P., \& Tsurganova, E. L. (2006). Ot moderna k postmodernizmu: logika razvitiya. Institut nauchnoi informazii po obshchestvennym naukam RAS: Chelovek:obraz I sushchnost. Moskva.

Kassim, M. (1994). Fragmenty modernizazii $i$ avangarda $v$ arabskoi literature. Devyataya konferenziya jegipetskikh pisatelei: Literatura i vyzov budushchemu. Kair. (in the Arabic language) عليـوة مستعد قاستــ

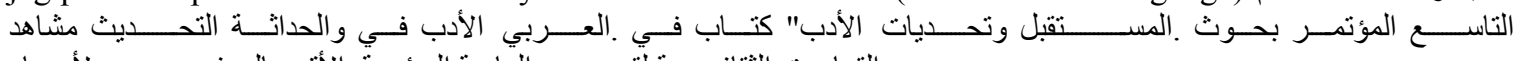

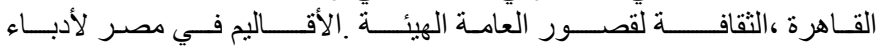

Kubareva, N. P. (2002). Zarubezhnaya literatura vtoroi poloviny 20 veka.

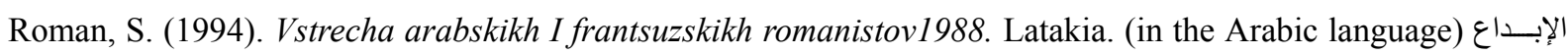

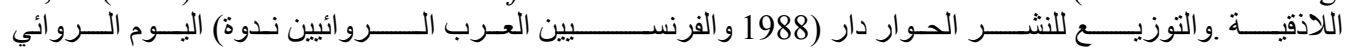

Sarukhanyan, A. P. (2010). K sootnosheniyu ponyatii “modernism”i “avangardism” IMLI RAN (9-33) Moskva.

Shibanov, V. L. (2007). Etnofuturism: mezhdu arkhaicheskim mifom i evropeiskim postmodernismom. Vestnik Udmurtskogo universiteta.

Stetsenko, E. A. (2002). Kontseptsiya traditsii v literature IMLI RAN: Khudozhestvennye orientiry zarubezhnoi literatury. Moskva.

Valgina, N. S. (1998). Teoriya teksta. Moskva.

\section{Copyrights}

Copyright for this article is retained by the author(s), with first publication rights granted to the journal.

This is an open-access article distributed under the terms and conditions of the Creative Commons Attribution license (http://creativecommons.org/licenses/by/3.0/). 